\title{
LIETUVOS SLIDININKŲ SPRINTERIŲ RENGIMO IR JÜ PARENGTUMO SPECIFINIAI BRUOŽAI PARENGIAMUOJU LAIKOTARPIU
}

\author{
Mantas Strolia, Juozas Skernevičius, Kazys Milašius
}

Vilniaus pedagoginis universitetas, Vilnius, Lietuva

\begin{abstract}
Mantas Strolia. Vilniaus pedagoginio universiteto Sporto pedagogikos magistrantūros studentas. Mokslinių tyrimų kryptis — didelio meistriškumo slidininkų rengimas.
\end{abstract}

\section{SANTRAUKA}

Nuo 2002 metu i žiemos olimpiniu žaidyniu programa itraukta slidinëjimo sprinto rungtis, kurios varžybinè veikla trunka 2-4 min. Tokios trukmès darbe reikšmingi yra tiek anaerobinis alaktatinis, tiek glikoltinis, tiek aerobinès energijos gamybos büdai. Anaerobiniu ir aerobiniu energijos gamybos procesu santykis sudaro po 50\%. Todèl iš pagrind u keičiasi slidininku sprinteriu rengimo technologija. Visgi tai reikètu pagrįsti moksliniais tyrinëjimais.

Tyrimo tikslas: atsižvelgiant i sprinto rungties reikšmès padidejjima, išanalizuoti Lietuvos olimpinès rinktinès slidininku (vyru) sprinteriu rengimasi parengiamuoju laikotarpiu ir atskleisti jo specifinius ypatumus, sportininku organizmo adaptacijos bruožus. Buvo organizuotas dvieju Lietuvos slidininku sprinteriu veiklos tyrimas. Trenerès parengti pratybu planai aptarti su moksline grupe. Sudaryti konkretūs mezo- ir mikro- ciklai, išsamiai aprašyti kiekvienos dienos pratybu planai, numatytas pratybu poveikio kryptingumas (uždaviniai). Fizinis krūvis registruotas sportininku dienoraščiuose, trenerio žurnale. Atskiru mezociklu veiksmingumui ̨̇vertinti buvo atliekami laboratoriniai tyrimai pagal programa „,Vankuveris-2010“. Buvo matuojami fizinio išsivystymo rodikliai, atlikti vienkartinio raumenu susitraukimo galingumo (VRSG) (Bosco et al., 1983), laiptinès ergometrijos anaerobinio alaktatinio raumenu galingumo (AARG) ir 10 s maksimaliu pastangu veloergometrijos testai. Mišraus anaerobinio alaktatinio ir glikolitinio energijos gamybos galingumui ivertinti taikytas 30 s veloergometrijos testas, glikolitiniam galingumui - 60 s veloergometrijos testas. Pagal šiq diagnostikos programa buvo ištirta 14 slidininku, iš ju 12 rengési ̌veikti ilguosius nuotoliuos, du - trumpuosius.

Nustatyta, kad Lietuvos slidininku sprinteriu rengimo turinys ir metodai iš esmés skiriasi nuo ilguju nuotoliu slidininku rengimo. Rengiant slidininkus sprinterius, ju anaerobiniam alaktatiniam galingumui ugdyti skiriama iki 20\% laiko. Jau antruoju etapu rengiamos glikolitini galinguma ir ištvermę ugdančios pratybos salèje, lauke. Ugdant aerobini pajéguma, vyrauja fiziniai krūviai, kuriu intensyvumas priartèja prie KIR ir sumažeja fizinio krūvio, kurio intensyvumas mažesnis už ANS intensyvuma, apimtis. Tirti slidininkai sprinteriai parengiamuoju laikotarpiu pasieke didelius anaerobinio ir aerobinio pajégumo rodiklius. Išlieka svarbus uždavinys pasiekta specialuji fizini parengtuma išlaikyti ìveikiant varžybu nuotolius.

Raktažodžiai: slidinëjimo sprintas, specialus fizinis krūvis, fizinis darbingumas, funkcinis pajėgumas, organizmo adaptacija.

\section{IVADAS}

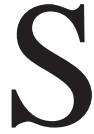
lidinèjimo lenktynių nuotoliai daugelį metų buvo ilgi. Moterų varžybinè veikla trukdavo nuo 15 min iki 1,5 h, vyrų - nuo 25 min iki 2,5 h. Tokio darbo metu vyrauja aerobinès energijos gamyba (Rusko, 2003; Čepulènas, 2006 a). Nuo 2002 metų i žiemos olimpinių žaidynių programą įtraukta slidinèjimo sprinto rungtis, kur varžybinè veikla trunka 2-4 min.
Tokios trukmės darbe reikšmingi tiek anaerobinis alaktatinis, tiek glikoltinis, tiek aerobinès energijos gamybos būdai. Anaerobinių ir aerobinių energijos gamybos procesų santykis sudaro po $50 \%$ (Čepulènas, 2006 b). Todèl iš pagrindų keičiasi slidininkų sprinterių rengimo technologija. Tačiau tai reikia pagristi moksliniais tyrimais. Dabar pasitaiko tyrimų, kurių metu sprinterių rengimo 
ypatumai analizuojami daugiau teorinių prielaidu pagrindu (Larionow, 2002; Čepulènas, 2007). Sporto mokslas žengia sportininkų rengimo praktikos priekyje. Pasirodo fundamentalūs tyrimai, kuriais naujai žvelgiama i didelio meistriškumo sportininkų rengimo turini, struktūrą (Бондарчюк, 2005; Issurin, 2008).

Kaip nurodo A. Čepulènas (2006 b), Italijos slidinejjimo rinktinès sprinterių $17,3 \%$ atlikto pratybų krūvio per 2002-2003 metų ciklą buvo skirta anaerobinèms reakcijoms skatinti, 44,5\% - darbui ties kritinio intensyvumo $\left(\mathrm{VO}_{2 \max }\right)$ riba, $38,1 \%$ krūvio sudare mažesnio intensyvumo pratimai.

Atsižvelgiant i nepakankamą informacijos kieki, sportininkų rengimo uždavinius aktualu išnagrinėti Lietuvos slidininkų sprinterių rengimosi eigą parengiamuoju laikotarpiu, kuriuo sportininkas parengiamas maksimalių pastangų darbui, t. y. tokiam, kai organizme vyksta specifiniai biocheminiai procesai (Волков и др., 2000; Gailiūnienè, Milašius, 2001).

Iškyla mokslinė problema išsiaiškinti sprinterių rengimo ir jų fizinio parengtumo ypatumus.

Tyrimo tikslas: atsižvelgiant i sprinto rungties reikšmès didèjima, išanalizuoti Lietuvos olimpinès rinktinès slidininkų (vyrų) sprinterių rengimąsi parengiamuoju laikotarpiu ir atskleisti jo specifinius ypatumus, sportininkų organizmo adaptacijos bruožus.

\section{TYRIMO ORGANIZAVIMAS IR METODAI}

Buvo organizuotas dviejų Lietuvos slidininku sprinterių veiklos tyrimas. Trenerès parengti treniruočiu planai buvo aptarti su moksline grupe. Sudaryti konkretūs mezo- ir mikro- ciklai, išsamiai aprašyti kiekvienos dienos pratybu planai, numatytas pratybu poveikio kryptingumas (uždaviniai). Atliktas fizinis krūvis buvo registruojamas sportininkų dienoraščiuose, trenerio žurnale. Parengiama išsami kiekvienų pratybų atlikimo informacinè medžiaga ir atlikto krūvio ataskaita mezociklo metu. Fizinių krūvių poveikiui (greitajai adaptacijai) įvertinti buvo registruojamas pulso dažnis (PD) per visas pratybas, sudaroma kompiuterinė PD kaitos diagrama. Glikolitiniu reakciju aktyvumui ivertinti nustatoma laktato (La) koncentracija kraujyje. Organizmo nuovargis ir adaptacijos eiga gauta registruojant PD ryte, tik prabudus ir vakare, atsigulus nakties poilsiui ir pailsejjus 5 min. Taip buvo sudaromos PD kaitos per mezociklą kreivès.
Atskiru mezociklų veiksmingumui įvertinti buvo atliekami laboratoriniai tyrimai pagal programą „Vankuveris-2010“. Buvo matuojami fizinio išsivystymo rodikliai: ūgis, svoris, apskaičiuojamas kūno masės indeksas (KMI), plaštaku jèga, gyvybinis plaučių tūris (GPT), raumenų, riebalų masè. Anaerobiniam alaktatiniam raumenu galingumui ivertinti taikyti trys testai: vienkartinio raumenu susitraukimo galingumo (VRSG) (Bosco et al., 1983), laiptinès ergometrijos anaerobinio alaktatinio raumenų galingumo (AARG) (Margaria et al., 1966) ir 10 s maksimalių pastangų veloergometrijos testas. Mišraus anaerobinio alaktatinio ir glikolitinio energijos gamybos galingumui ivertinti buvo taikytas $30 \mathrm{~s}$ veloergometrijos testas (Bar-Or, 1987), glikolitiniam galingumui - 60 s veloergometrijos testas (Szögy, Cherebetin, 1979).

Aerobinis galingumas ties kritinio intensyvumo riba (KIR) ir anaerobinio slenksčio (ANS) riba buvo nustatoma sportininkui bėgant bėgtakiu, pakeltu $10^{\circ}$ kampu ir kvėpuojant per dujų analizatorių. Buvo fiksuojama plaučių ventiliacija (PV), $\mathrm{PD}$, absoliutus ir santykinis $\mathrm{VO}_{2 \text { max }}$ bei $\mathrm{VO}_{2}$, deguonies pulso (DP) rodikliai.

Kraujotakos sistemos funkciniam pajègumui ivertinti buvo registruotas PD gulèjus $5 \mathrm{~min}$, reakcija ị ortostatinį mėgini, ị standartinį fizinị krūvị (30 atsitūpimų per $45 \mathrm{~s}$ ) ir atsigaunant per $60 \mathrm{~s}$, apskaičiuojamas Rufjè indeksas (RI) (Skernevičius ir kt., 2004).

Šia diagnostikos programa buvo ištirta 14 slidininkų, iš jų 12 rengèsi startuoti ilgujų ir du trumpuju nuotoliu varžybose. Medžiagos analizei atlikti buvo taikyti matematinès statistikos metodai, apskaičiuoti aritmetiniai vidurkiai $(\overline{\mathrm{X}})$, standartiniai nuokrypiai (S), sudaryti standartizuotu (normalizuotų) rodiklių profiliai.

\section{REZULTATAI}

Lietuvos olimpinės rinktinės slidininkų sprinteriu parengiamasis laikotarpis prasidejjo 2008 metu gegužę ir tęsèsi šešis mėnesius. Jis buvo suskirstytas $\mathfrak{i}$ tris etapus. Pirmas - nuoseklus fizinių krūvių didinimo etapas (gegužès, birželio mèn.). Antras - didelio fizinio krūvio etapas (liepos, rugpjūčio mèn.). Trečias - specialiojo fizinio rengimo etapas (rugsėjo, spalio mèn.). Kiekvieną etapą sudarè du mezociklai. Jie buvo sudaryti iš keturių mikrociklų. Pirmas mikrociklas buvo ivvadinis, antras ir trečias - didelių fizinių krūvių, ketvirtas - skirtas atsigavimui, superkomepnsaci- 

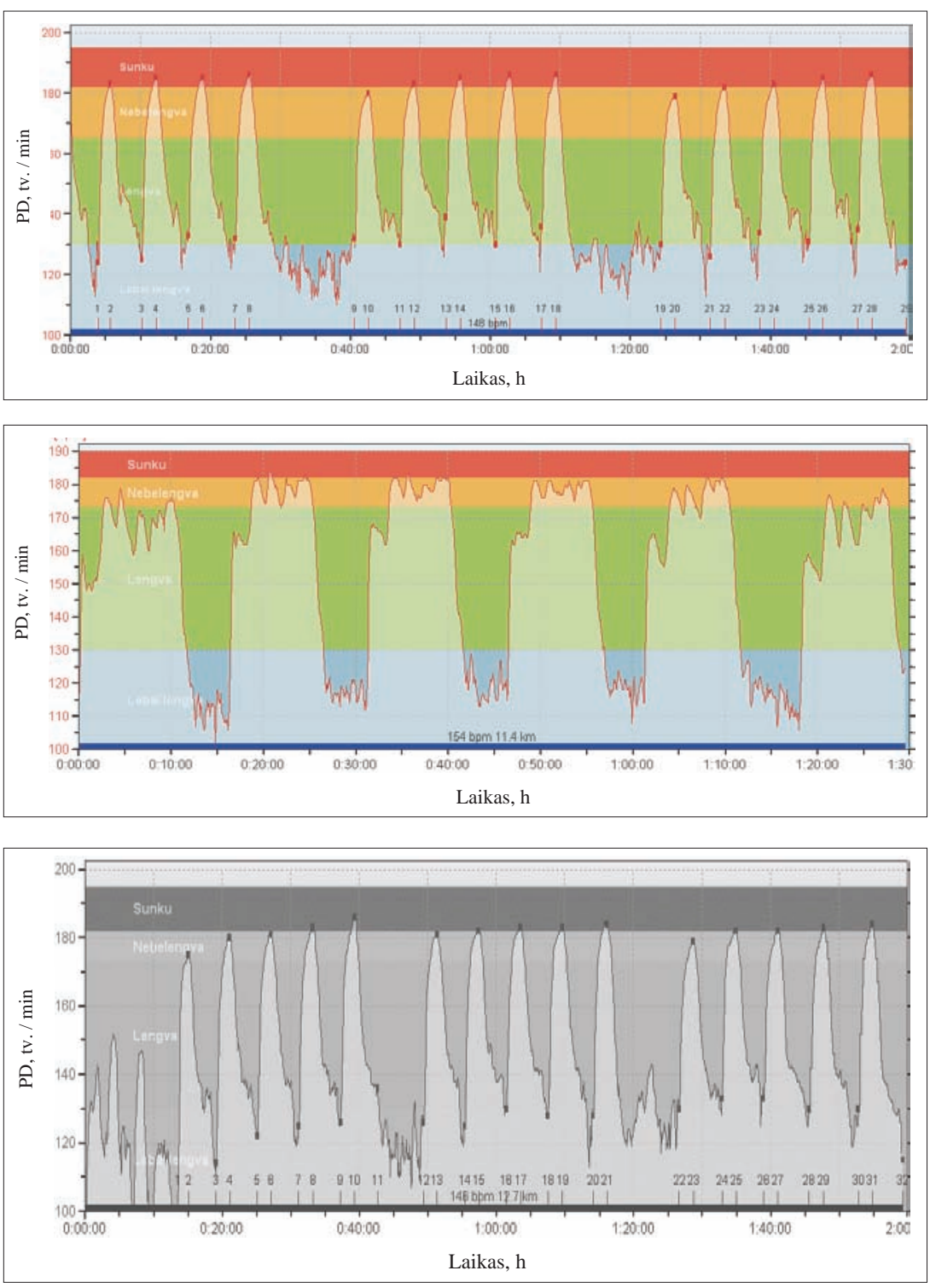

1 pav. Sportininko M. S. pulso dažnio kreivè per glikolitinio galingumo ugdymo pratybas
2 pav. Sportininko M. S. pulso dažnio kreivè per maksimalaus aerobinio pajègumo ugdymo pratybas
3 pav. Sportininko M. S. pulso dažnio kreivẻ per anaerobinio glikolitinio galingumo ir ištvermès ugdymo pratybas niams reiškiniams. Treniruočiu mikrociklą sudarè du laiko tarpsniai organizmui nuvarginti ir jam atsigauti.

Pirmuoju rengimo etapu vyravo aerobinès energijos apykaitos reikalaujantys fiziniai krūviai, kurie sudarė $80 \%$ bendrosios krūvio apimties, o $20 \%$ - anaerobini alaktatini raumenu̧, kurie atlieka pagrindini darbą slystant su slidėmis, galingumą ugdantis darbas (šuoliai, darbas treniruokliu salèje su įrankiais). Šių pratimų metu judesių greitis buvo panašus judesių greičiui per slidinėjimo sprinto varžybas.

Antruoju etapu i rengimo programą pradèta itraukti glikolitinio galingumo ugdymo pratybas. Vienerios iš tokiu pratybų buvo šuoliu imitacija $(375 \mathrm{~m} \times 5) \times 3$. Poilsis tarp kartojimu $-4-5 \mathrm{~min}$, tarp seriju $-15 \mathrm{~min}$. PD siekè 180-186 tv. / min, La koncentracija - 12,213,2 mmol / l. 1 paveiksle pateikta šių pratybų metu užfiksuota PD kreivè. Panašaus pobūdžio pratybos derinamos su važiavimu riedslidėmis aerobinio ugdymo intensyvumo zonoje, laktato koncentracijai kraujyje neviršijant $4 \mathrm{mmol} / \mathrm{l}$, ir pratybomis, ugdančiomis anaerobini alaktatini specialių raumenų grupių galingumą su įrankiais, rato stotiniu arba srautiniu metodu. Vienerių tokių pratybų rato stotiniu pavyzdys: (15 s trukmès darbas, poilsis $60 \mathrm{~s}) \times 5$, poilsis $4 \mathrm{~min}$, tempimo pratimai, tokiu pat būdu atliekamas kitas pratimas. Per 56 min buvo atlikti šeši pratimai. Aerobiniam galingumui ugdyti buvo taikomos pratybos dirbant ties anaerobinio slenksčio ir kritinès intensyvumo zonos riba (laktato koncentracija - 6-8 mmol / l), darbo dalių trukmé 10 -20 min. 2 paveiksle pateikta tiriamojo pulso dažnio kreivé tokiu pratybų metu.

Trečią etapą sudare du mezociklai (rugsèjo ir spalio mėn.). Pirmo mezociklo pagrindinis darbas atliktas vidutiniame $1450 \mathrm{~m}$ aukštyje virš jūros lygio. Pratybose 40\% laiko buvo skirta ae- 
4 pav. Sportininko M. S. pulso dažnio kreivẻ per mišraus anaerobinio glikolitinio ir aerobinio pajègumo ugdymo pratybas
5 pav. Slidininko sprinterio M. S. pulso dažnio kreivè, užregistruota $1050 \mathrm{~m}$ virš jūros lygio stovykloje (2008 10 0910 23)
6 pav. Slidininkų sprinterių standartizuotu rodiklių profiliai
Pastaba. S - standartinis nuokrypis. 1. Ūgis, cm. 2. Svoris, kg. 3. Parankinès plaštakos jèga, kg 4. GPT, l. 5. Raumenų masė, kg. 6. VRSG, W. 7. AARG, W. 8. 10 s darbo galingumas, W. 9. $30 \mathrm{~s}$ darbo galingumas, W. 10. $60 \mathrm{~s}$ darbo galingumas, W. $11 . \mathrm{VO}_{2} \max$ $\mathrm{ml} / \mathrm{mim} / \mathrm{kg}$ 12. Deguonies pulsas, $\mathrm{ml} / \mathrm{tv}$. 13. Deguonies suvartojimas ties anaerobinio slenksčio riba, ml / min / kg. 14. Deguonies suvartojimas ties anaerobinio slenksčio riba nuo $\mathrm{VO}_{2} \max , \%$.
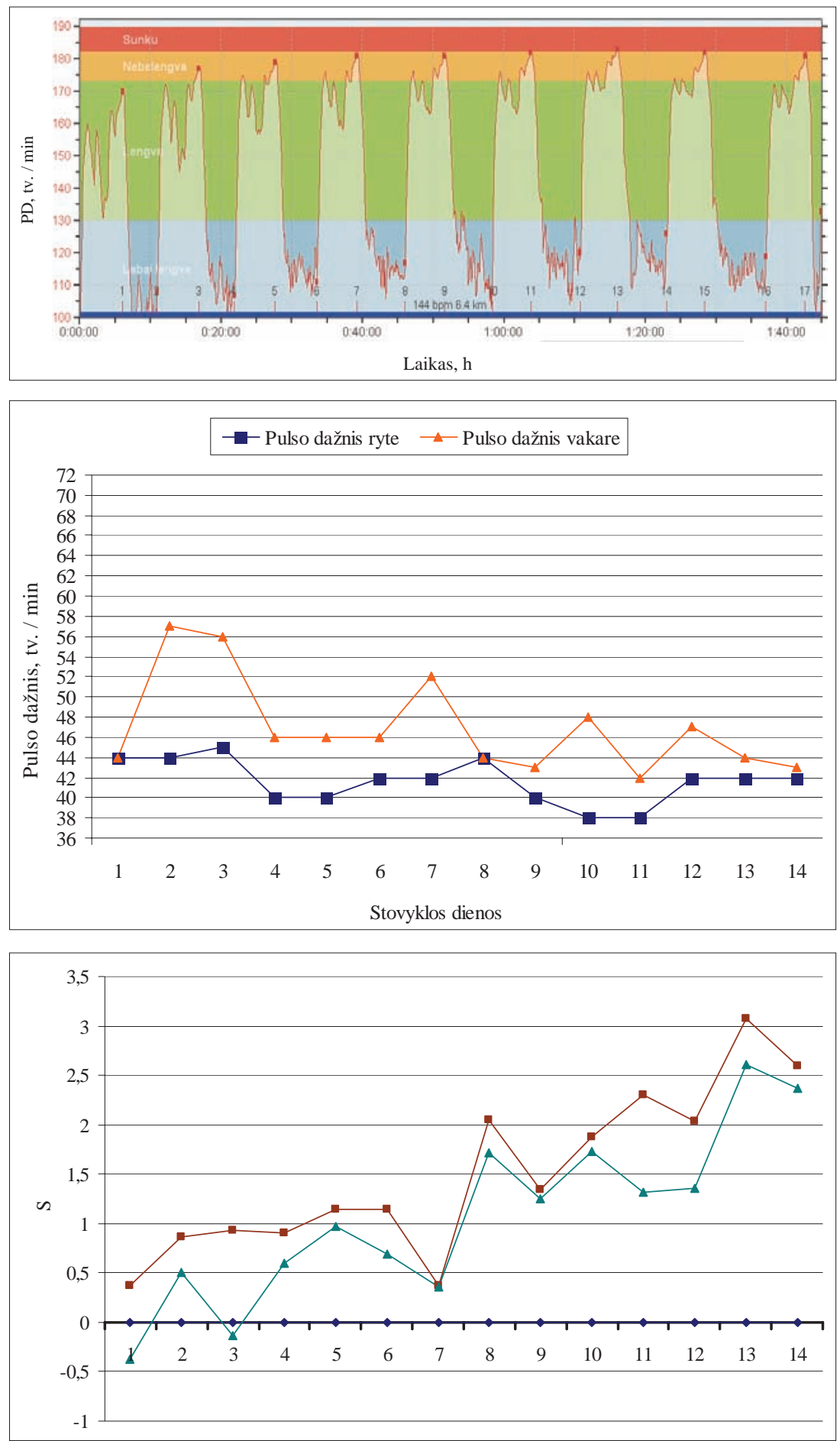

robiniam pajėgumui ugdyti, 30\% — anaerobiniam alaktatiniam ir 30\% - glikolitiniam galingumui. Atliekant pratybas su irrankiais, buvo dirbama 15, 30 ir 40 s. Dirbant 15 s, laktato koncentracija kraujyje didejo iki 5-6 mmol / l, dirbant $30 \mathrm{~s}$ - iki $7-8 \mathrm{mmol} / \mathrm{l}$, dirbant $40 \mathrm{~s}-\mathrm{iki}$ 9,0-15,0 mmol / 1 .

Anaerobinis alaktatinis galingumas buvo ugdomas ir važiuojant riedslidèmis arti anaerobinio slenksčio intensyvumo ribos ir greitėjant ((10$15 \mathrm{~s}) \times 10-12 \mathrm{k}$. .).
Glikolitinis galingumas dar buvo ugdomas šuoliais imituojant slydimo pakaitini dvižingsnị i kalną ((1-2 min $\times 5 \mathrm{k}) \times 3$ serijos $)$. Po tokių pratybų laktato koncentracija kraujyje pasieke 13,214,2 mmol / l, poilsis tarp darbo daliu — 3-5 min, tarp serijų - 12-15 min. PD po šių darbo dalių siekè 180-185 tv. / min, atsigavimo pabaigoje sumažèdavo iki 110-120 tv. / min (3 pav.).

Mišriam aerobiniam ir anaerobiniam pajègumui ugdyti buvo atliekamos pratybos dirbant po 5-10 min, kai pulso dažnis padidèdavo iki 


\begin{tabular}{|c|c|c|c|c|c|c|c|c|c|c|c|c|c|c|c|}
\hline \multirow{3}{*}{ 葛 } & \multirow{3}{*}{ 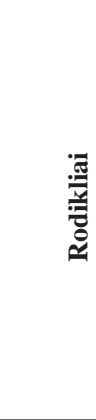 } & \multirow[b]{2}{*}{ 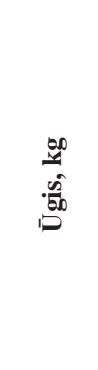 } & \multirow[b]{2}{*}{ 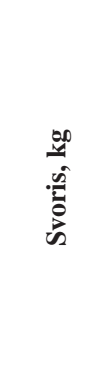 } & \multirow[b]{2}{*}{ 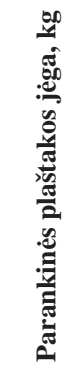 } & \multirow[b]{2}{*}{$\stackrel{\overrightarrow{0}}{\hat{0}}$} & \multirow[b]{2}{*}{ 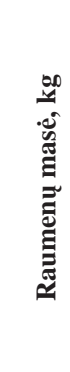 } & \multirow[b]{2}{*}{\begin{tabular}{l}
3 \\
$\hat{N}$ \\
\multirow{2}{*}{}
\end{tabular}} & \multirow[b]{2}{*}{ 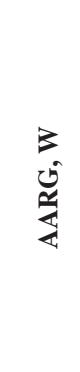 } & \multicolumn{3}{|c|}{ Galingumas } & \multirow[b]{2}{*}{ 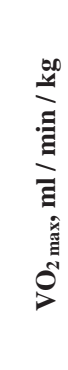 } & \multirow[b]{2}{*}{$\begin{array}{l}\Xi \\
\hat{\hat{\theta}}\end{array}$} & \multirow[b]{2}{*}{ 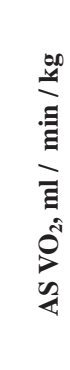 } & \multirow[b]{2}{*}{ 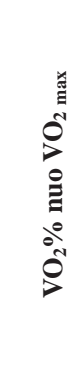 } \\
\hline & & & & & & & & & $\begin{array}{l}3 \\
\dot{5} \\
0\end{array}$ & $\begin{array}{l}3 \\
\text { m } \\
\text { ले }\end{array}$ & $\begin{array}{l}3 \\
\dot{\omega} \\
8\end{array}$ & & & & \\
\hline & & 1 & 2 & 3 & 4 & 5 & 6 & 7 & 8 & 9 & 10 & 11 & 12 & 13 & 14 \\
\hline \multirow{2}{*}{ Sl. } & $\bar{X}$ & 180,25 & 73,70 & 49,6 & 5,1 & 40,4 & 2013 & 1313 & 1036 & 610 & 470 & 63,8 & 26,0 & 49,1 & 74,8 \\
\hline & $\mathrm{S}$ & 5,93 & 8,64 & 12,2 & 1,1 & 5,3 & 419 & 360 & 412 & 112 & 88 & 6,2 & 4,4 & 6,5 & 5,9 \\
\hline \multirow{2}{*}{ Sp. } & 1 & 178,0 & 81,0 & 62,0 & 6,1 & 46,3 & 2406 & 1145 & 1741 & 749 & 623 & 78,6 & 35,3 & 66,5 & 88,7 \\
\hline & 2 & 182,5 & 78,0 & 48,0 & 5,8 & 45,3 & 2485 & 1461 & 1875 & 759 & 625 & 74,4 & 31,8 & 64,0 & 89,3 \\
\hline
\end{tabular}

180-185 tv. / min, laktato koncentracija po šio krūvio - iki 8-10 mmol / l (4 pav.).

Pagrindinis antro mezociklo darbas buvo atliktas mokomojoje treniruočiu stovykloje aukštikalnėse. Gyventa ir dalis pratybų atlikta $1050 \mathrm{~m}$ aukštyje, o ant sniego su slidėmis buvo dirbta $2600 \mathrm{~m}$ aukštyje. Tokiomis sąlygomis buvo sudètinga reguliuoti darbo intensyvuma, didelis aukščiu skirtumas pasunkino organizmo adaptacijos procesus.

Dirbant su slidèmis anaerobiniam slenksčiui artimu intensyvumu, buvo didinamas aerobinis pajëgumas, stiprinamas kraujotakos ir kvėpavimo sistemos funkcinis pajėgumas. Raumenų specialioji galia buvo ugdoma atliekant 8-12 s trukmès greitejjimus galingai pasispiriant kojomis ir stipriai pasistumiant rankomis, bet nedidinant judesiu tempo. Anaerobinis alaktatinis specialių raumenu grupiu galingumas buvo ugdomas ir dirbant su irankiais iki $15 \mathrm{~s}$ rato srautiniu metodu.

Glikolitinis galingumas ugdytas dirbant su irankiais po $60 \mathrm{~s}$ (laktato koncentracija kraujyje po tokio krūvio sieke 9-10 mmol / l) ir šuoliais imituojant pakaitini dvižingsni i kalną po $2-2,5 \mathrm{~min}$ (laktato koncentracija po tokio krūvio siekè 13$14 \mathrm{mmol} / \mathrm{l}, \mathrm{PD}=180-185 \mathrm{tv} . / \mathrm{min})$.

6-10 kartu kartojant 5-10 min trukmès fizinị krūvị (pulso dažniui didejjant iki $180 \pm 3 \mathrm{tv}$. / min, laktato koncentracijai - iki 7 -9 mmol / l), buvo ugdomas galingumas ties kritinio intensyvumo riba ir ištvermè, didinamas $\mathrm{VO}_{2 \text { max }}$. Per parengiamaji laikotarpi vyko 178 pratybos, dirbta $403 \mathrm{~h}$.

Varžybų laikotarpis prasidejjo lapkričio mėnesi. Jo metu jau buvo startuota dvejose varžybose.

Sportininkų organizmo adaptacijos eigai diagnozuoti buvo atliekami išplèstiniai tyrimai VPU
Sporto mokslo institute, Vilniaus miesto sporto medicinos centre parengiamojo laikotarpio pradžioje ir pabaigoje. Etapiniai tyrimai atlikti po kiekvieno etapo VPU Sporto mokslo institute. Mezociklų metu mokomosiose treniruočių stovyklose kiekvieną dieną buvo registruojamas pulso dažnis ryte tik prabudus ir vakare atsigulus poilsiui. Pavyzdys pateikiamas 5 paveiksle - slidininko M. S. pulso dažnio kreivé, užregistruota stovykloje aukštikalnėse.

Norėdami paanalizuoti ir iškelti sprinteriu parengtumo tyrimo duomenu ypatumus, juos palyginome su ilgưu nuotolių slidininkų analogiškais duomenimis. Lentelejje pateikti pagrindiniai sportininkų fizinio išsivystymo, fizinių ir funkcinių galių rodikliai, grupès aritmetiniai vidurkiai ir standartiniai nuokrypiai, parodantys rodikliu sklaidą. Norint palyginti pateikti asmeniniai sprinto rungčių slidininkų rodikliai. Greta - sprinterių standartizuotų rodiklių profiliai (6 pav.), grafiškai parodantys, kiek jų standartizuoti rodikliai nutolę nuo visos grupès vidurkių. Tyrimas atskleide, kad sprinteriu ūgio rodikliai yra mažai nutolę nuo grupės vidurkio. Abu sprinteriai turi kur kas didesnę kūno masę negu stajeriu grupès vidurkio rodiklis. Pirmo sprinterio parankesnès plaštakos jẻga yra labai didelè, antro - artima grupės vidurkiui. GPT sprinteriu rodikliai buvo daug didesni. Sprinterių raumenų masè taip pat didesnè (5-6 kg). Nagrinėjant slidininkų galios rodiklius îvairios trukmės darbo metu matyti, kad sprinteriu VRSG kur kas didesnis už grupès vidurki, o AARG skiriasi mažiau, tačiau pranašumas akivaizdus. Ypač didelė abiejų sprinteriu galia nustatyta atliekant 10 ir $30 \mathrm{~s}$ trukmès darba, kuris parodo mišrią anaerobinę alaktatinę ir glikolitinę galią, rodiklių standartizuotos 
reikšmės mažiau nutolusios nuo grupės vidurkio. $60 \mathrm{~s}$ trukmès glikolitinès galios rodikliai nuo kitu slidininkų vidurkio smarkiai nutolę. Taigi atliekant darbą, kurio metu dominuoja anaerobinès reakcijos, sprinteriai rodo kur kas didesnę galią negu ilgujų nuotolių slidininkai.

Aerobini pajėgumą ties kritinio intensyvumo riba parodantys sprinteriu rodikliai $\left(\mathrm{VO}_{2 \max }, \mathrm{DP}\right)$ taip pat yra didesni negu grupés vidurkiai. Ypač dideli sprinterių deguonies suvartojimo rodikliai ties anaerobinio slenksčio riba, ir tai sudaro atitinkami 88,7 ir $89,9 \%$ nuo $\mathrm{VO}_{2 \text { max }}$.

\section{REZULTATŲ APTARIMAS}

Slidinejjimo sprinto rungtys - tai visai naujas reiškinys pasaulio slidinejjimo sporto raidoje. Visai neseniai išleistame vadovèlyje „Slidinèjimas“ (Skernevičius ir kt., 2005) dar nėra aptarti slidininku sprinterių rengimo ypatumai. Tai daryti dar nebuvo teorinio, mokslinio ir praktinio pagrindo. Praejjus metams A. Čepulėnas (2006), remdamasis kitų valstybių slidininkų sprinterių rengimo medžiaga ir pateikdamas tyrimo duomenų iš mūsu šalies slidininku rengimo praktikos, analizuoja slidininkų sprinterių rengimo ypatumus. Lietuvoje specialiai rengtis slidinèjimo sprinto rungtims pradèta tik 2008 metais. Tokio rengimosi parengiamuoju laikotarpiu medžiaga apibendrinama šiame straipsnyje. Išryškèjo pagrindiniai rengimosi ypatumai. Slidininku sprinterių rengimo vyksme labai padidejjo fiziniai krūviai, ugdantys anaerobinị alaktatinį raumenų galingumą. Tokio pobūdžio fizinio krūvio, rengiant slidininkus ilgujų nuotolių varžyboms, anksčiau buvo atliekama labai mažai (Skernevičius, Skernevičienè, 1979; Čepulènas, 2001).

Glikolitines reakcijas skatinantis fizinis krūvis pradėtas taikyti antruoju rengimo etapu. Laktato koncentracija kraujyje siekè iki 12-14 mmol / l. K. Milašiaus (1997) tyrimais nustatyta, kad slidininkai, ilgujų nuotolių lenktynininkai parengiamuoju laikotarpiu taip nesuaktyvindavo glikolitiniu reakcijų, nors L. Hermansen (1971) nurodo, kad sportininkai, atliekantys iki $8 \mathrm{~min}$ trukmès darbą, pasiekia dar didesnę laktato koncentraciją kraujyje (iki 20 ir daugiau mmol / l). Glikolitinès reakcijos buvo aktyvinamos dirbant su įrankiais ir įtraukiant specialiąsias raumenu grupes i 30-60 s trukmès darba, kai jis kartojamas - 20-25 kartų (laktato koncentracija kraujyje sieke 8-12 mmol / l). Taigi atlikti tyrimai rodo, kad sportininkai dar turi galimybių didinti glikolitinių reakcijų aktyvumą. Ilgujų nuotolių slidininkai parengiamuoju laikotarpiu aerobiniam pajègumui ugdyti skiria $80 \%$ viso pratybu laiko, atliekamo neviršijant anaerobinio slenksčio ribos (La 4 mmol / l). Mūsų tirti slidininkai sprinteriai aerobiniam pajègumui ugdyti $\left(\mathrm{VO}_{2}\right.$ max didinimui) šiuo laikotarpiu atliko po $1-2$ pratybas per mikrociklą, iveikdami 5-10 min trukmès darbo dalis, po kuriu laktato koncentracija sieké 8-10 $\mathrm{mmol} / \mathrm{l}$.

Pakartotiniai slidininkų tyrimai ir statistinè duomenų analizè parengiamuoju laikotarpiu parodè, kad slidininkai sprinteriai, mažai besiskirdami ūgiu nuo slidininku grupès vidurkio, daug labiau išugdè raumenų masę. Galima teigti, kad tam turejjo įtakos pratimai, atliekami anaerobiniu galingumu alaktatinès energijos gamybos zonoje (Astrand, Rodahl, 1986; Rusko, 2003).

Ugdant raumenu galingumą, veiksmai buvo atliekami greitai. Ši aplinkybė labai paveikè anaerobinio galingumo didejjimą. Parengiamuoju laikotarpiu taikytos pratybos didino $\mathrm{VO}_{2} \max$ rodiklius, taip pat $\mathrm{O}_{2}$ suvartojimą ties anaerobinio slenksčio riba. Šie sprinterių rodikliai yra labai nutolę nuo grupès vidurkio ir priarteję prie $\mathrm{VO}_{2 \text { max }}$ rodikliu (88,7 ir 89,3\%). Tai labai didelis procentinis rodiklis. N. Imšajevas, E. Širkovecas (Имшаев, Ширковец, 1980) nurodo, kad slidininku deguonies pulsas siekia $17-22 \mathrm{ml}$, mūsų tirtų slidininkų vidurkis buvo didesnis, o sprinterių — dar didesnis. Pulso dažnis ir laktato koncentracijos sprinteriu kraujyje tyrimai per pratybas leidžia pagristai įvertinti sportininku greitosios adaptacijos eigą, o pulso dažnio registracija ryte ir vakare teikia informaciją apie nuovargi ir atsigavimo eiga paros metu, per mikrociklus bei mezociklus.

\section{IŠVADOS}

1. Lietuvos slidininkų sprinterių rengimo turinys ir metodai iš esmès skiriasi nuo ilgujų nuotolių slidininkų rengimo:

- rengiant slidininkus sprinterius, jų anaerobiniam alaktatiniam galingumui ugdyti skiriama iki 20\% laiko;

- jau antruoju etapu rengiamos glikolitini galingumą ir ištvermę ugdančios pratybos salèje, lauke;

- ugdant aerobini pajėgumą, vyrauja fiziniai krūviai, kurių intensyvumas priartėja prie kritinio intensyvumo ribos, sumažèja fizinio krūvio apimtis, kurio intensyvumas yra 
mažesnis už intensyvumą ties anaerobinès apykaitos slenksčiu.

2. Tirti slidininkai sprinteriai parengiamuoju laikotarpiu pasieke didelius tiek anaerobinio, tiek aerobinio pajègumo rodiklius. Ju vienkartinis raumenu susitraukimo galingumas, glikolitinis galingumas, aerobinio pajègumo rodikliai smarkiai viršijo slidininku grupės vidurkius.

\section{LITERATŪRA}

Astrand, P. O. Rodahl, K. (1986). Textbook of Work Physiology. New York: Mc Graw- Hill.

Bar-Or., O. (1987). The Wingate anaerobic test. An update on methodology, reliability and validity. Sports Medicine, 28, 35-39.

Bosco, C., Komi, P., Tihanyj, J., Fekete, C., Apor, P. (1983). Mechanical power test and fiber composition of human leg extensor muscle. European Journal of Applied Physiology, 51, 129-135.

Čepulènas, A. (2007). Elito slidininkų lenktynininku varžybinès veiklos charaktersitika. Sporto mokslas, 3 (49), 7-14.

Čepulènas, A (2006 a). Lietuvos olimpinès rinktinės slidinėjimo rinktinés kandidatų treniravimo ypatumai. Slidinejjimo pratybu mezociklai vasaros ir rudens laikotarpiu. Sporto mokslas, 1 (43), 78-84.

Čepulènas, A. (2001). Slidininku rengimo technologija: monografija. Kaunas: LKKI.

Čepulènas, A. (2006 b). Slidinèjimo sprintas. Kaunas. LKKA.

Gailiūnienè, A., Milašius, K. (2001). Sporto biochemija. Vilnius: LSIC.

Hermansen, L. (1971). Muscle Metabolism During Exercise. New-York. P. 401-407.

Issurin, V. (2008). Block periodization. Breakthrough in sport training. In M. Yassis (Ed.), Ultimate Athlete Concepts. USA: Michigan.

Larionow, A. (2002). Metodyka przygotowania zawodnikow $w$ narciarstvie biegowym na roznych etapach szkolenia. Katowice: Akademia wychowania fizycznego w Katowicach.

Lietuvos sportininku rengimo ir dalyvavimo XXI žiemos olimpinèse žaidynése programa „Vankuveris 2010“. (2007). Vilnius: LSIC.
Margaria, R., Aghemo, P., Rovelli, E. (1966). Measurement of muscular power (anaerobic) in man. European Journal of Applied Physiology, 21, 1662-1664.

Milašius, K. (1997). Ištvermę lavinančiu sportininku organizmo adaptacija prie fiziniu krūviu. Vilnius.

Rusko, H. (2003). Physiology of cross-country skiing. Handbook of sports medicine and science cross-country skiing. H. Rusko (Ed.). (pp. 1-31). Blackwell Science.

Skernevičius, J., Milašius, K., Čepulènas, A., Dadelienė, R. (2005). Slidinejjimas. Vilnius.

Skernevičius, J., Raslanas, A., Dadelienè, R. (2004). Sporto mokslo tyrimu metodologija. Vilnius: LSIC.

Skernevičius, J. Skernevičienė, B. (1979). LTSR slidininku lenktynininku ruošimas IV TSRS tautu žiemos spartakiadai. Vilnius.

Szögy, A., Cherebetin, G. (1979). Minuten Test auf dem Fahrradergometer zur Bestimung der anaeroben Capacitat. European Journal of Applied Physiology, 33, 171-176.

Бондарчюк, А. (2005). Периодизаиия спортивной тренировки. Киев: Олимпийская литература.

Волков, Н. И. Несен, Э. М., Осипенко, А. А. Корсун, С. Н. (2000). Биохимия мышечной деятельности. Киев: Олимпийская литература.

Имшаев, Н. И., Ширковец, А. (1980). Особенности планирования тренировочной нагрузки лыжников гонщиков при подготовке к соревнованиям на различные дистанции. Лыжный спорт, 2, 27-29. 


\title{
SPECIFIC FEATURES OF LITHUANIAN SKI SPRINTERS' TRAINING AND THEIR FITNESS DURING THE PREPARATORY PERIOD
}

\author{
Mantas Strolia, Juozas Skernevičius, Kazys Milašius \\ Vilnius Pedagogical University, Vilnius, Lithuania
}

\begin{abstract}
Since 2002 the event of skiing sprint has been included into the programme of Winter Olympic Games. This event lasts from 2 to 4 minutes. Anaerobic alactic, glycolytic and aerobic methods of energy production are relevant in the work of such duration and the proportion of anaerobic and aerobic energy production processes is $50 \%$ to $50 \%$. Therefore, the technology of ski sprinter training technology has to undergo radical changes but this has to be scientifically substantiated.

The aim of the research was to analyse the training of Lithuanian Olympic team of male ski sprinters in the preparatory period considering an increase in the significance of sprinter event and to reveal its specific particularities and features of organism adaptation. The research in the activity of two Lithuanian ski sprinters was conducted and the training plans drawn up by the coach were discussed with the research group members. The specific mesocycles and microcycles were developed, training plans for every day were thoroughly described and purposiveness (objectives) of the effect of practical training sessions were established. The performed physical load was registered in the athletes' diaries and the register of the coach. The efficiency of separate mesocycles was measured conducting laboratory works within the programme 'Vancouver-2010'. The indices of physical development and single muscle contraction capacity (SMCC) (Bosco et al, 1983) were estimated; the gradual ergometry test for measuring of anaerobic alactic muscular capacity (AAMC) and $10 \mathrm{~s}$ maximal work veloergometric test were conducted. The capacity of mixed anaerobic alactic glycolytic energy was estimated with the help of $30 \mathrm{~s}$ veloergometric test and glycolytic capacity was measured during $60 \mathrm{~s}$ veloergometric test. This diagnostic programme included 14 skiers: 12 long-distance skiers and 2 sprinters.

It was established that the content and methods of Lithuanian ski sprinters' training differ considerably from that of long-distance skiers. About $20 \%$ of the time used for training of ski sprinters is devoted to the development of anaerobic alactic capacity. In the second phase of training, the athletes train in the hall and outside and develop their glycolytic capacity and endurance. The aerobic capacity training is based on physical loads intensity of which approximate the critical intensity limit (CIL). The volume of physical load of lower intensity than an anaerobic threshold (AnT) decreases. During the preparatory period, the ski sprinters in the research demonstrated high indices of anaerobic and aerobic capacity. The most important objective is to transfer the achieved special physical fitness into activity with skis in the competitive distances.
\end{abstract}

Keywords: ski sprint, special physical load, physical work capacity, functional capacity, body adaptation.

Gauta 2009 m. sausio 19 d.

Received on January 19, 2009

Priimta 2009 m. kovo 5 d.

Accepted on March 5, 2009

Kazys Milašius

Vilniaus pedagoginis universitetas

(Vilnius Pedagogical University)

Studentų g. 39, LT-08106 Vilnius

Lietuva (Lithuania)

Tel +370 52734858

E-mail kazys.milasius@vpu.lt 